\title{
The Tonal Residue of the Conjoint/Disjoint Alternation in Rukiga
}

\author{
Jenneke van der Wal \& Allen Asiimwe \\ Leiden University \& Makerere University
}

\begin{abstract}
The Bantu language Rukiga (JE14, Uganda) shows tonal reduction on the verb in a subset of tenses, similar to the conjoint/disjoint alternation in Haya. Whereas in other languages the conjoint/disjoint alternation is usually marked by segmental morphology in at least one tense, Rukiga is unique in showing only tonal reduction. Nevertheless, our analysis shows that tonal reduction in Rukiga is not merely a phonological rule, but it encodes the conjoint/disjoint alternation. Furthermore, we show that tonal reduction in Rukiga is determined by constituent-finality, and there is no direct relation to focus.
\end{abstract}

Keywords: tone, focus, Bantu, conjoint/disjoint, phrasing

\section{Introduction: the conjoint/disjoint alternation}

Some southern and eastern Bantu languages display an alternation between two verb forms that express the same tense-aspect semantics, but differ in their relation with what follows the verb. When the relation is close (French 'conjoint'), the verb takes the so-called conjoint form and cannot appear in a clause-final position of a main clause (1b). The disjoint form, on the other hand, is allowed in clause-final position (1c).

Kinyarwanda (JD61, Ngoboka \& Zeller 2017: page)

a. Abagoré baáteetse inyama.

a-ba-goré ba-á-téek-ye i-nyama

AUG-2-woman 2SM-REM-cook-PFV AUG-10.meat

'Women cooked meat.'

b. *Abagoré baáteetse.

a-ba-goré ba-á-téek-ye

[remote past CJ]

AUG-2-woman 2SM-REM-cook-PFV

c. Abagoré baáratéetse.

[remote past DJ]

a-ba-goré ba-á-ra-téek-ye
AUG-2-woman 2SM-REM-DJ-cook-PFV
'Women cooked.'

[remote past CJ]

The distinction between the two forms is visible in the segmental and/or tonal morphology of the verb - in Kinyarwanda, the remote past conjoint form as in (1a) undergoes tonal reduction (-teetse vs. -téetse) and the remote past disjoint form is marked by the prefix -ra-, as in (1c). In terms of interpretation, the conjoint form is typically associated with focus on the element following the verb, either directly or indirectly, whereas the disjoint form is associated with focus on the predicate or truth value. The relation with focus will be discussed in more detail in section 3, and see Van der Wal (2017) for further crosslinguistic variation in the alternation. 
Part of the variation in this alternation is that not every language or even every tense within a language marks the alternation as clearly as the Kinyarwanda remote past. For Haya, Hyman (1999: 160) describes "one last trace of the conjoint/disjoint opposition", which is the today past tense: the disjoint form is marked by a long prefix -áá-, whereas the conjoint form has a short - $a$ - prefix, as in (2).

Haya (JE22, Hyman 1999: 160)

(2) a. CJ Y-a-koma Káto

1SM-P1-tie 1.Kato

'He tied Kato.'

b. DJ Y-áá-mu-kôma.

1SM-P1.DJ-1OM-tie

'He tied him.'

Furthermore, the conjoint form in (2a) has undergone tonal reduction (TR): the lexical high (H) tone of the verb stem -kóm- is absent, in contrast to the disjoint form, which retains its $\mathrm{H}$. This tonal reduction turns out to be characteristic for other tenses in Haya as well, even if they do not show segmental marking. This is illustrated in Table 1, where the right-hand column shows the tonally reduced 'conjoint' forms (see also Odden 1997 for TR in Zinza):

Table 1 Haya tonal reduction (Hyman 1999: 160)

\begin{tabular}{|l|l|l|}
\hline & 'they tie' etc. & 'they tie Káto' etc. - TR \\
\hline present habitual & ba-kóm-a & ba-kom-a káto \\
\hline past 1 & bá-á-kôm-a & ba-a-kom-a káto \\
\hline past 2 & ba-kom-1́le & ba-kom-ile káto \\
\hline past habitual & ba-a-kóm-ag-a & ba-akom-ag-a káto \\
\hline future 1 & ba-laa-kôm-a & ba-laa-kom-a káto \\
\hline future 2 & ba-li-kóm-a & ba-li-kom-a káto \\
\hline
\end{tabular}

A bit further north, in Rukiga, ${ }^{1}$ we find a similar alternation of H-retaining verb forms in final position (3a) vs. tonally reduced forms when an object follows $(3 b){ }^{2}$

a. H María y-áá-híinga.

1.Maria 1SM-N.PST-dig

'Maria has dug.'

b. TR María y-aa-hiingá o-mu-siri.

1.Maria 1SM-N.PST-dig AUG-3-field

'Maria has dug the field.'

\footnotetext{
${ }^{1}$ Rukiga is classified as JE14 in Maho's (2009) update of Guthrie (1948), and is spoken in south-western Uganda by some 2.4 million speakers (Ethnologue online). The data in this paper come from fieldwork by the authors in January 2019 in Kabale, and additional judgements are from the second author, who is a native speaker of Rukiga. The language is often grouped together with the neighbouring language Runyankore, though there are lexical and grammatical differences. Even within the variants of Rukiga there is variation, especially in tone patterns. The tones used in this paper are based on Orunyaifo variety predominantly spoken in Ndorwa County in Kabale District.

${ }^{2}$ For the relevant examples we indicate the presence of tonal reduction on the verb by 'TR', and the absence by ' $\mathrm{H}$ '.

${ }^{3}$ Naturally, this is pronounced with liaison as yaahiing' ómusiri, and the final $\mathrm{H}$ appears on the augment of the object.
} 
However, unlike Haya, Rukiga never shows any segmental marking of the alternation. This triggers the question whether this purely tonal distinction in Rukiga should be analysed as encoding the conjoint/disjoint alternation - similarly to the research question Kula (2017) poses for Bemba tone marking on verbs. Surprisingly, we find that Rukiga is the first language that shows evidence for a purely tonal conjoint/disjoint alternation. We present our analysis as follows. In section 2, we introduce the formal properties of the alternating conjugations, specifically the tones in different combinations of verbs and objects, and the sentence-final distribution. Section 3 then applies tests to establish the possible relation with focus, concluding that constituent-final distribution (not focus) is the determining factor for tonal verb forms in Rukiga. Section 4 discusses the research question in light of the presented facts.

\section{Four conjugations with tonal reduction}

In order to establish which conjugational categories ('tenses') have tonal reduction, we first need to introduce some tonal properties and rules to appreciate the tonal complexity of inflected verbs in Rukiga. The first piece of information is the lexical difference between verb stems that have a lexical $\mathrm{H}$ tone versus toneless or L stems, ${ }^{4}$ as can be seen in the infinitive form, which takes the prefix oku-.

$\begin{array}{llll}\begin{array}{l}\text { H-toned stems } \\ \text { oku-bóha }\end{array} & \text { 'to tie' } & \begin{array}{l}\text { L-toned/toneless stems } \\ \text { oku-gura }\end{array} & \text { 'to buy' } \\ \text { oku-téeka } & \text { 'to cook' } & \begin{array}{l}\text { oku-reeba } \\ \text { oku-kurura }\end{array} & \text { 'to see' } \\ \text { oku-búgana } & \text { 'to mull' }\end{array}$

The second ingredient are the $\mathrm{H}$ tones introduced in inflection. The inflectional prefixes as well as the final vowel on the verb may have a $\mathrm{H}$ tone associated with them, as Hyman \& Byarushengo (1984) show for Haya verb tone. This is indicated in the formulas for the seven conjugations (plus infinitive) that we consider here ${ }^{5}$ as in Table 2. Obligatory parts of each conjugation are the subject marker (SM), the verbal base (VB, consisting of the root plus applicative, causative, passive etc. derivations), and the final suffix (-a, -e, or -ire). The four conjugations that have a $\mathrm{H}$ final suffix are indicated as $\mathrm{H}$ in the first column.

Table 2 - Formulae for verbal conjugations in Rukiga

\begin{tabular}{|l|l|l|l|l|}
\hline & conjugation & formula & example & translation \\
\hline & infinitive & oku-VB-a & oku-bóh-a & to tie \\
\hline & remote future & SM-ryáá-VB-a & ba-ryáá-bóh-a & they will tie \\
\hline H & present progressive & ni-SM-VB-á & ni-ba-bóh-a & they are tying \\
\hline H & subjunctive & SM-VB-é & tu-bóh-e & may we tie \\
\hline H & present/ habitual & SM-VB-á & ba-bóh-a & they tie \\
\hline H & yesterday past & SM-VB-íre & ba-boh-íre & they tied \\
\hline & remote past & SM-ka-VB-a & ba-ka-bóh-a & they tied \\
\hline & near past & SM-á-VB-a & b-áá-bóh-a & they have tied \\
\hline
\end{tabular}

From the examples in Table 2 we can also observe a tonal rule that is attested in other Bantu languages: a phrase-final vowel may not be H (Poletto 1998a: 63). Therefore the final vowel

\footnotetext{
${ }^{4}$ We will not discuss the theoretical question of whether non-H morae in Rukiga are better analysed as toneless or low, as it does not affect our argument. See Poletto (1998a) for discussion.

${ }^{5}$ Other tense/aspect categories are expressed periphrastically in Rukiga, by an auxiliary and either an infinitive or an inflected lexical verb (see Morris \& Kirwan 1972 and Taylor 1985 for overviews). These are not taken into account here.
} 
of the progressive, subjunctive, and habitual all come out as $\mathrm{L}$, despite the underlying $\mathrm{H}$ on the final suffix.

Evidence for the final $\mathrm{H}$ comes from the comparison between $\mathrm{H}$-toned and L-toned verbs. As seen in Table 3, the progressive, subjunctive, habitual, and yesterday past also show a $\mathrm{H}$ tone on a L-toned verb stem (-kurura). This $\mathrm{H}$ cannot come from the verb stem. Furthermore, it cannot be an automatically added phrase-final $\mathrm{H}$, because in that case we would expect the remote past to also show a $\mathrm{H}$, which it does not (*bakakurúra). We conclude that the four indicated tenses have an inflectional $\mathrm{H}$ on the final suffix.

Table 3 - Rukiga conjugations for H-toned and L-toned verbs

\begin{tabular}{|l|l|l|l|l|}
\hline & conjugation & formula & H-toned V & L-toned V \\
\hline & infinitive & & okubúgana & okukurura \\
\hline & remote future & SM-ryáá-VB-a & baryáábúgana & baryáákurura \\
\hline H & present progressive & ni-SM-VB-á & nibabugána & nibakurúra \\
\hline H & subjunctive & SM-VB-é & tubugáne & tukurúre \\
\hline H & present/ habitual & SM-VB-á & babugána & bakurúra \\
\hline H & yesterday past & SM-VB-íre & babugí́ne & bakurwîre \\
\hline & remote past & SM-ka-VB-a & bakabúgana & bakakurura \\
\hline & near past & SM-á-VB-a & báábúgana & báákurura \\
\hline & & & meet/find & pull \\
\hline
\end{tabular}

Furthermore, if an inflectional $\mathrm{H}$ on the final suffix is present, the lexical $\mathrm{H}$ on the stem does not surface (Poletto 1998a for Nkore-Kiga, see also Hyman \& Byarushengo 1984: 64). In Table 3 , the progressive, subjunctive, habitual, and yesterday past all lack a $\mathrm{H}$ tone on the stem of a $\mathrm{H}$ toned verb: the underlying form -búgan- HL (as in the infinitive) becomes -bugan- LL. The inflectional $\mathrm{H}$ on the final suffix then shifts one mora to the left because it would otherwise occur on the phrase-final vowel, so that -buganá LLH comes out as -bugána LHL. The perfective -íre suffix does not change, as it is unaffected by the ban on phrase-final Hs. ${ }^{6}$ Note that the difference between lexically $\mathrm{H}$-toned and L-toned verbs still determines where the inflectional $\mathrm{H}$ is realised.

In order to assess whether these tenses show the "conjoint/disjoint" tonal reduction as in Haya, we need to examine the behaviour of each of these conjugational categories in final position versus non-final position. The full paradigms are given in Table 4 and Table 5, for H-toned verbs and L-toned verbs respectively. ${ }^{7}$ Three relevant tonal observations can be made here.

\footnotetext{
${ }^{6}$ The restriction to one $\mathrm{H}$ on the (macro)stem is known from earlier research on Nkore-Kiga (Poletto 1998a) and other languages in the area (e.g. Haya, Hyman \& Byarushengo 1984). While this may be due to the general OCP in the domain of the verb stem, it is not likely a case of Meeussen's rule, whereby the second of two adjacent Hs gets deleted: in Rukiga it seems to be the first that is deleted, and furthermore, two adjacent Hs do not seem to be problematic for the near past: ba-á-búgana (unless the underlying form is ba-áa-búgana, in which case the two Hs would not be adjacent - thanks to Larry M. Hyman for pointing out this possibility).

${ }^{7}$ The semantics of these verb+object combinations may not make much sense, but they do allow us to study the tones of longer verbs followed by objects that start with a consonant. This is relevant in order to see the tone on the final vowel of the verb, because naturally, liaison would take place between the final vowel of the verb, and the initial vowel of the object, e.g. babugana omuuntu > babugan'ómuuntu.
} 
Table 4 - Rukiga conjugations for H-toned verb, final and non-final position

\begin{tabular}{|l|l|l|l|l|l|}
\hline & & conjugation & final & H object & L object \\
\hline & & infinitive & okubúgana & okubúgana búrahaanda & okubúgana muha \\
\hline & & remote future & baryáábúgana & $\begin{array}{l}\text { baryáábúgana } \\
\text { búrahaanda }\end{array}$ & $\begin{array}{l}\text { baryáábúgana } \\
\text { muha }\end{array}$ \\
\hline & H & $\begin{array}{l}\text { present } \\
\text { progressive }\end{array}$ & nibabugána & nibabuganá búrahaanda & nibabuganá muha \\
\hline & H & subjunctive & tubugáne & tubugané búrahaanda & tubugané muha \\
\hline TR & H & present/ habitual & babugána & babugana búrahaanda & babuganá muha \\
\hline TR & H & yesterday past & babugíne & babugiine búrahaanda & babugiiné muha \\
\hline TR & & remote past & bakabúgana & bakabugana búrahaanda & bakabuganá muha \\
\hline TR & & near past & báábúgana & baabugana búrahaanda & baabuganá muha \\
\hline & & & meet/find & meet/find pancakes & meet/find the fox \\
\hline
\end{tabular}

Table 5 - Rukiga conjugations for L-toned verb, final and non-final position

\begin{tabular}{|l|l|l|l|l|l|}
\hline & & conjugation & final & H object & L object \\
\hline & & infinitive & okukurura & okukurura búrahaanda & okukururá muha \\
\hline & & remote future & baryákurura & baryákurura búrahaanda & baryákururá muha \\
\hline & H & present progressive & nibakurúra & nibakurúra búrahaanda & nibakurúra muha \\
\hline & H & subjunctive & tukurúre & tukurúre búrahaanda & tukurúre muha \\
\hline TR & H & present/ habitual & bakurúra & bakurura búrahaanda & bakururá muha \\
\hline TR & H & yesterday past & bakurwîre & bakurwire búrahaanda & bakurwiré muha \\
\hline TR & & remote past & bakakurura & bakakurura búrahaanda & bakakururá muha \\
\hline TR & & near past & báákurura & baakurura búrahaanda & baakururá muha \\
\hline & & & pull & pull pancakes & pull the fox \\
\hline
\end{tabular}

The first observation is that in the bottom four tenses (the habitual and the three past tenses), the verb appears as completely $\mathrm{L}$ when followed by an object with a lexical $\mathrm{H}$ tone, like búrahaanda 'pancakes'. This is the tonal reduction that we are interested in, hence indicated in the tables as 'TR'. Tonal reduction applies to both H-toned and L-toned verbs, and to conjugations with a final $\mathrm{H}$ and without - all tonally reduced forms are in the shaded cells in Table 4 and Table $5 .{ }^{8}$

The second observation is that in those TR conjugations, it makes a difference whether the following object has a lexical $\mathrm{H}$ tone or not. As just noted, if the object brings its own $\mathrm{H}$ (on the first mora), the verb can remain all-L: bakakurura búrahaanda. In contrast, if the object is itself all-L (muha 'fox'), the final vowel of the verb becomes H in these four TR tenses: bakakururá muha. This is the same regardless of the lexical tone class of the verb (compare the TR rows for Table 4 and Table 5), and regardless of the tone on the final suffix (compare the habitual and yesterday past on the one hand versus the remote and near past on the other hand). Considering that the pattern is

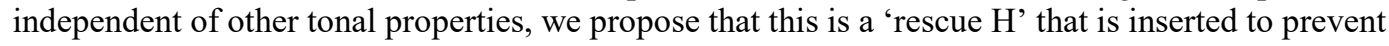
the occurrence of a completely low verb phrase.

A third observation concerns the progressive and subjunctive. Like the habitual and the yesterday past they feature a $\mathrm{H}$ final suffix, as evidenced by the $\mathrm{H}$ appearing on lexically $\mathrm{L}$ verbs. As observed earlier, this $\mathrm{H}$ on the final suffix results in the non-occurrence of the lexical $\mathrm{H}$. When nothing follows the verb, the final $\mathrm{H}$ surfaces on the penultimate mora, because of the constraint

\footnotetext{
${ }^{8}$ Note that the remote past of a L-toned verb stem does not carry any $\mathrm{H}$ tone whatsoever, resulting in the same form in final and non-final position: bakakurura 'they pulled (pancakes)'. We can either say that the remote past does not have a tonal reduction alternation when the verb is L-toned, or that the application of TR is invisible in case the verb and conjugation do not bear a $\mathrm{H}$ tone. The second option is more harmonious and thus opted for here.
} 
against final $\mathrm{H}$ morae. When any object follows the verb, we observe a difference between $\mathrm{H}$-toned and L-toned verbs: the final vowel is $\mathrm{H}$ on $\mathrm{H}$-toned non-final verbs, and the penultimate vowel is $\mathrm{H}$ on L-toned non-final verbs. We have no further analysis of this pattern, but the important point here is that the subjunctive does not show tonal reduction like the four TR conjugations do. If it would, we would expect to encounter the all-L verb form tukurure/tubugane búrahaanda.

Another significant point with respect to tonal reduction is the fact that the same tenses do not show a tonally reduced form in the negative, where both the final and non-final form show the same tonal pattern: ${ }^{9}$

Table 6 - Rukiga negative conjugations

\begin{tabular}{|c|c|c|c|c|c|c|}
\hline & & conjugation & $\begin{array}{l}\text { H-toned } \\
\text { final }\end{array}$ & $\begin{array}{l}\text { H-toned non- } \\
\text { final }\end{array}$ & $\begin{array}{l}\text { L-toned } \\
\text { final }\end{array}$ & $\begin{array}{l}\text { L-toned non- } \\
\text { final }\end{array}$ \\
\hline & & $\begin{array}{l}\text { infinitive } \\
\text { (aff.) }\end{array}$ & okutéeka & $\begin{array}{l}\text { okutééka } \\
\text { búrahanda }\end{array}$ & okureeba & $\begin{array}{l}\text { okureeba } \\
\text { búrahaanda }\end{array}$ \\
\hline TR & $\mathrm{H}$ & $\begin{array}{l}\text { present/ } \\
\text { habitual }\end{array}$ & tibáteeka & $\begin{array}{l}\text { tibáteeka } \\
\text { búrahaanda }\end{array}$ & tibaréeba & $\begin{array}{l}\text { tibarééba } \\
\text { búrahaanda }\end{array}$ \\
\hline TR & $\mathrm{H}$ & yesterday past & tibateekíre & $\begin{array}{l}\text { tibateekiré } \\
\text { búrahaanda }\end{array}$ & tibaréébire & $\begin{array}{l}\text { tibaréébire } \\
\text { búrahaanda }\end{array}$ \\
\hline TR & & remote past & tibaráteekire & $\begin{array}{l}\text { tibaráteekire } \\
\text { búrahaanda }\end{array}$ & tibaráreebire & $\begin{array}{l}\text { tibaráreebire } \\
\text { búrahaanda }\end{array}$ \\
\hline \multirow[t]{2}{*}{ TR } & & near past & tíbaateeka & $\begin{array}{l}\text { tíbaateeka } \\
\text { búrahaanda }\end{array}$ & tíbaareeba & $\begin{array}{l}\text { tíbaareeba } \\
\text { búrahaanda }\end{array}$ \\
\hline & & & $\begin{array}{l}\text { not cook, } \\
\text { bake }\end{array}$ & $\begin{array}{l}\text { not make } \\
\text { pancakes }\end{array}$ & $\begin{array}{l}\text { not see, } \\
\text { watch }\end{array}$ & not see pancakes \\
\hline
\end{tabular}

Tonally reduced verb forms cannot appear in final position in a main clause, as illustrated for the present habitual and the yesterday past in (5). This is typical of the conjoint form of the conjoint/disjoint alternation - see (1b) above.
a. A-b-áana ba-záana / *ba-zaana.
AUG-2-children 2SM-play
'Children play.'
b. Ekikópo, Hélen akitwííre / *akitwiiré.
e-ki-kopo Helen a-ki-twar-ire
AUG-7-cup 1.Helen 1SM-7OM-take-PFV
'The cup, Helen took it.'
[present habitual]

While the tonally reduced form has so far been illustrated with a following object, it is equally acceptable with a following adverb, as shown in (6) - as long as the reduced form is not final.

a. TR Wiiruka munóonga.
w-a-iruka munoonga
2SG.SM-N.PST-run much
'You have run fast.'

\footnotetext{
${ }^{9}$ The long vowels in -teeka and -reeba bring another constrain into the picture: no LH rising syllables are allowed in Rukiga, as is the same in other languages in the region (e.g. Hyman \& Byarushengo 1984 for Haya).
} 
b. TR Tukutegyeeriize nyómwéébázo. ${ }^{10}$

tu-ku-tegyerez-ire nyomwebazo

1PL.SM-2SG.OM-wait-PFV yesterday

'We waited for you yesterday.'

The tonal reduction thus clearly shows the sentence-final restrictions, a defining feature of the conjoint/disjoint alternation. Furthermore, the alternation occurs in a restricted number of conjugational categories, as is also typical of the conjoint/disjoint alternation. Having presented the formal properties, we can now turn to the interpretational properties of tonal reduction in Rukiga.

\section{Focus or finality?}

In the Bantu languages that have the conjoint/disjoint alternation, it is directly or indirectly related to focus. In languages like Kirundi and Makhuwa, the form of the verb is directly related to the focus interpretation, whereas in languages like Zulu the form of the verb depends on whether it is final in its constituent or not. We briefly illustrate this before testing the focus predictions for Rukiga.

In Kirundi, the disjoint verb form expresses predicate focus (Nshemezimana \& Bostoen 2017), and the conjoint form is the default. Predicate-centred focus can be sub-divided into state-ofaffairs focus (focus on the lexical verb itself, as in (7)), TAM focus (8), and truth focus (9). All three are expressed by the disjoint form in Kirundi, regardless of the constituent-final or non-final position of the verb.

Kirundi (JD62, Nshemezimana \& Bostoen 2017: 408, 409, 410)

(7) Ehe ntaa co turiiyé, turanyóoye gusa.

Ehe ntaa ki-ó tu-rí-ye ${ }^{\mathrm{H}}$ tu- $\varnothing$-ra-nyó-ye gusa

so NEG.COP 7-REF 1PL.SM-eat-PFV.REL 1PL.SM-PRS-DJ-drink-PFV only

"So, there is nothing that we eat, we DRINK ONLY." (Agashitsi, drama, 1990s)

(8) Q: Nooné yaamaze gushika?

A: Oya aracáakúba igoónzi.

nooné a-a-a-mar-ye ku-shik-a

so 1SM-N.PST-DJ-finish-PFV 15-arrive-FV

oya a-ra-cáa-kúb-a i-ø-goónzi

no 1SM-DJ-PERS-tremble-IPFV AUG-5-convulsion

Q: "So, HAS he ALREADY PASSED AWAY?"

A: "No, he IS STILL IN AGONY." (Gikenye, theatre, 1970s)

(9) Q: Nooné murí aya magúme, abashíingaántahe hári icó baáfashije?

A: Abashíingantaáhe kóko baárafáshije.

nooné mu-rí a-a ma-gúme a-ba-shíingantaáhe ha-ø-ri

QW 18LOC 6- $\mathrm{DEM}_{\mathrm{a}}$ 6-crisis AUG-2-traditional.councillor 16SM-PRS-be

i-ki-ó ba-á-ø-fásh-ye

AUG-7-REF 2SM-REM.PST-help-PFV.REL

a-ba-shíingaántahe kóko ba-á-ra-fásh-ye

AUG-2-traditional.councillor obviously 2SM-REM.PST-DJ-help-PFV

Q: "Were the traditional councillors by any means helpful during that crisis?"

A: “The traditional councillors DID OBVIOUSLY HELP.” (Mushingantahe, peace, 2000s)

${ }^{10}$ Note that the non-reduced form is also acceptable here; the reduced form indicates focus on the adverb. See (29) below for a parallel example. 
In Makhuwa, the conjoint verb form expresses focus on the element following the verb, and the disjoint is the elsewhere form. This can for example be seen when the postverbal noun is the potentially indefinite noun $n t t h u$ 'person': because of the focus on the postverbal element, this object cannot be interpreted as a non-specific indefinite when it follows a conjoint verb form (10b), instead resulting in a generic reading (10c). The disjoint verb form is perfectly fine when followed by a non-specific indefinite (10a), showing that the form of the verb is not determined by finality of the verb, but by the focus interpretation of the element following the verb.

Makhuwa (P31, Van der Wal 2011: 1740)

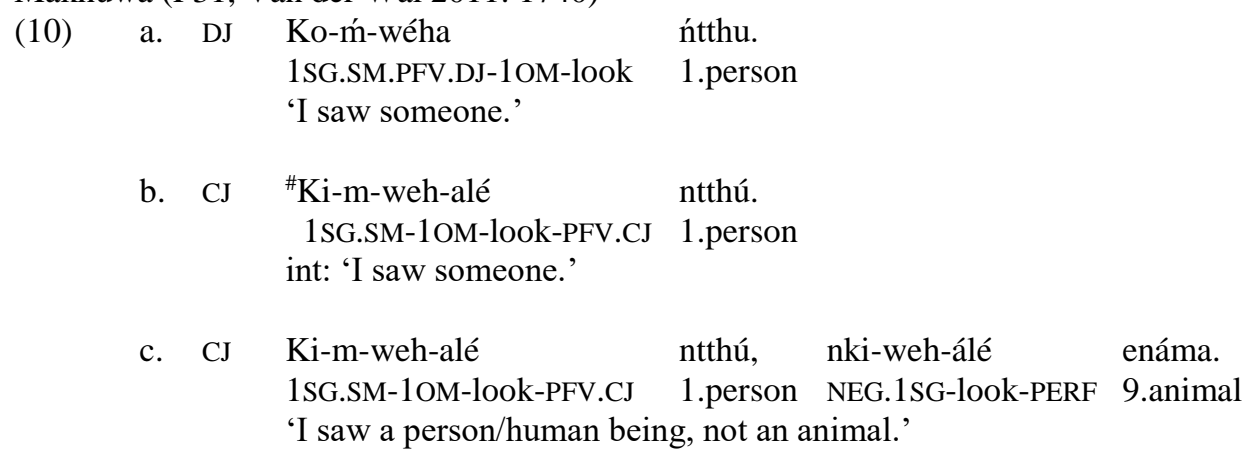

In Zulu, focused elements need to occupy a position within the vP (Buell 2006, Cheng \& Downing 2009). When such an element is present in a postverbal position, this entails that the verb is not final in its vP constituent. Such non-finality, in turn, is what selects the conjoint form of the verb - even if the element following the verb is not in focus, the conjoint form will still appear, as in (11). Conversely, the disjoint form is chosen when the verb is final, regardless of whether it is in (one type of) predicate-centred focus. Cheng and Downing (2009) show that phonological phrasing also marks constituency: the right boundary of a phonological phrase is marked by lengthening of the penultimate syllable. The right-dislocation of an object thus affects the phonological phrasing as well as the form of the verb, as seen in (12). The relation with focus is therefore an indirect one in Zulu, mediated by constituent-finality (13) (Van der Spuy 1993, Buell 2006, Buell 2009, Halpert 2017).

Zulu (S42, Buell 2005: 64, 66)

$\begin{array}{lllll}\text { CJ A-ngi-dans-i } & \text { kahle, kodwa } & \text { ngi-cul-a } & \text { kahle. } \\ \text { NEG-1SG.SM-dance-FV well but } & \text { 1SG.SM-sing-FV } & \text { well } \\ \text { 'I don't dance well, but I sing well.' } & & \end{array}$
a. DJ Abafana [ba-ya-si-hlu:pha] isaluka:zi.
2.boys 2SM-PRS.DJ-7-annoy 7.old.woman
b. CJ Abafana [ba-hlupha isaluka:zi.]
2.boys 2SM-annoy 7.old.woman
'The boys are annoying the old woman.'

(13) a. $\left[\mathrm{V}_{\text {CONJOINT } \mathrm{X}}\right]_{\mathrm{vP}}(\mathrm{Y})$

b. $\left[\mathrm{V}_{\text {DISJOINT }}\right]_{\mathrm{vP}}(\mathrm{X})(\mathrm{Y})$

We now want to test whether the observed tonal alternation in Rukiga is sensitive to focus or constituency. If the pattern of tonal reduction in Rukiga were determined by focus, there could be 4 possible correlations (based on Buell 2006, see also Van der Wal 2017): 
1. predicate-centred focus requires the non-reduced ('disjoint') form;

2. no tonal reduction ('disjoint') entails predicate-centred focus;

3. tonal reduction ('conjoint') entails focus on the postverbal element;

4. a focused postverbal element requires tonal reduction on the verb ('conjoint' form).

These correlations will be tested in turn in the next subsections, illustrated with verbs inflected in the near past and yesterday past tense.

3.1 PCF requires no TR While it is true that in many cases of predicate-centred focus the verb is indeed in its non-reduced (disjoint) form, the verb is also in the majority of those cases in a constituent-final position. In (14) and (15), the lexical verb is contrasted, while (16) focuses on the truth value.

(14) (What did father do with the beans and the carrots?)

Tááta e-bi-híimbá a-bi-teek-íre, károt y-áá-zí-koota.

1.father AUG-8-beans 1SM-8OM-cook-PFV 10.carrot 1SM-N.PST-10OM-eat.raw

'Father, the beans he cooked; the carrots he ate raw.'

(15) Tí-ba-a-karaang' é-bi-nyóobwa, bá-á-bi-shékura.

NEG-2SM-N.PST-roast AUG-8-groundnuts 2SM-N.PST-8OM-pound

'They didn't roast the groundnuts, they pounded them.'

(16) (The cook didn't come.)

Iizíre!

a-ij-ire

1SM-come-PFV

'He came. / He did come.'

However, as soon as the verb is not constituent-final, but still in focus, tonal reduction (conjoint) is required. In (17) and (18), a contrast is created between two lexical actions creating state-of-affairs focus, while an adverb follows the verb. Only the tonally reduced form is acceptable.

a. TR E-nyonyi tí-z-a-taambura júba koonká z-aa-guruka júba. AUG-10.birds NEG-10SM-N.PST-walk quickly but 10SM-N.PST-fly quickly 'The birds have not walked quickly, they have flown quickly.'

b. H *Enyonyi tízatambura júba konká zááguruka júba.
a. TR E-i-shóki ti-n-aa-ri-shokoza gye AUG-5-hair NEG-1SG.SM-N.PST-5OM-comb well koonká n-aa-ri-sibá gye. but 1SG.SM-N.PST-plait well

'The hair, I have not combed it well but I have plaited it well.'

b. H *Eishóki tinaarishokoza gye konká náárísibá gye.

The first correlation thus does not hold; instead we find a relation with constituent-finality.

3.2 No TR entails PCF. The second possible correlation is that the absence of tonal reduction ('disjoint') entails predicate-centred focus. This again seems to hold true at first glance, but again 
those verb forms are also always constituent-final. In (19), the postverbal object is right-dislocated, leaving the verb in a constituent-final position.

$$
\begin{aligned}
& \text { a. H Ba-mu-kom-íré o-mu-shúma. } \\
& \text { 2SM-1OM-tie-PFV AUG-1-thief } \\
& \text { 'They imprisoned him, the thief.' }
\end{aligned}
$$

b. TR *Bamukomire omushúma.

We know that in (19) the object is dislocated because of the presence of the coreferring object marker - since in Rukiga object markers function as pronouns and cannot co-occur in the same domain with their coreferring DP object (20), we know that the DP object forms a separate constituent.
a. *Píta y-áá-ka-téeka
a-ka-húúnga e-ri-zóoba.
1.Peter 1SM-N.PST-12OM-cook
AUG-12-posho AUG-5-day int. 'Peter cooked posho today.'
b. Píta y-áá-ka-téek' e-ri-zóob' a-ka-húúnga.
1.Peter 1SM-N.PST-12OM-cook AUG-5-day AUG-12-posho
'Peter cooked it today, posho.'

Another environment to test the correlation is when an agreeing subject appears in a linearly postverbal position. This is not a case of agreeing inversion (one of the subject inversion constructions listed in Marten \& Van der Wal (2014)), for two reasons. First, unlike in locative inversion and default agreement inversion (DAI), the tonally reduced verb form is in fact unacceptable with a postverbal agreeing subject, as seen in the comparison between DAI in (21) and the agreeing subject in (22).
a. TR Ha-a-shohora Píta.
16SM-N.PST-move.out 1.Peter
'Peter left.' / 'It's Peter who left.'

b. H *Hááshohora Píta.
a. H B-áá-shek' á-bá-ana. (agreeing subject)
2SM-N.PST-laugh AUG-2-children
'Children have laughed.' / 'They have laughed, the children.'

b. TR *Baasheka abáana.

Second, the postverbal agreeing subject can scope over negation. This is significant in comparison with default agreement inversion (where the subject marker is a default class $16 \mathrm{ha}$-), as seen in (23a). Assuming that the postverbal logical subject is in situ in default agreement inversion, the possibility of the subject scoping higher suggests that the agreeing postverbal subject in (23b) has moved out of the vP.

(23) a. Tíhaayeesyaamur' énte zóona. (default agreement inversion)
ti-ha-a-esyaamura
e-n-te
z-oona
NEG-16SM-N.PST-sneeze AUG-10-cows 10-all
*'All cows did not sneeze.'
'Not all cows sneezed.' 
b. Tízaayeesyaamur' énte zóona. (agreeing subject)

ti-zi-a-esyaamura e-n-te z-oona

NEG-10SM-N.PST-sneeze AUG-10-cows 10-all

'All cows did not sneeze.'

'Not all cows sneezed.'

This comparison indicates that in the VS order in (23b), the verb is left as the only constituent in the vP, that is, it is constituent-final. We conclude that there is no convincing evidence that the second potential correlation between verb form and focus holds in Rukiga.

3.3 TR entails postverbal focus The third potential correlation is that tonal reduction ('conjoint') entails focus on the postverbal element. This correlation does not hold; there are plenty of counterexamples. If the element following the tonally reduced verb form would necessarily be in focus, we would predict cognate objects, parts of idioms, and indefinite non-specifics to be ungrammatical following a tonally reduced verb form. This is because each of these cannot trigger alternatives and is therefore 'unfocussable'. The opposite is true: tonal reduction is obligatory for each of these, as shown in (24) to (27).

(24) a. TR Naayeeyaguz' órugusyo.

n-aa-eyaguza o-ru-gusyo

1SG.SM-N.PST-scratch.CAUS AUG-11-shard

'I was in a bad situation.'

b. H *Nááyééyaguz' orugúsyó.

a. TR N-aa-zin' é-ki-zíno.

1SG.SM-N.PST-dance AUG-7-dance

'I danced a dance.'

b. H N-áá-zína.

1SG.SM-N.PST-dance

'I danced.'

c. H *Náázín' ékizíno.

(26)

a. TR M-byaam-ir' ó-tú-ro.

1SG.SM-sleep-PFV AUG-13-sleep

'I slept a sleep.'

b. H *M-byaam-ír' ó-tú-ro /*mbyaamíre otúro.

1SG.SM-sleep-PFV AUG-13-sleep

'I slept a sleep.'
a. TR N-aa-reeb' ó-muu-ntu.
1SG.SM-N.PST-see AUG-1-person
'I saw someone.'

b. H *Nááréeb' omuuntu. 

c. TR Mpulir' ómuuntu.
n-hurir-ire o-mu-ntu
1SG.SM-hear-PFV AUG-1-person
'I heard someone.'

d. H *Mpulíír' ómuuntu.

Furthermore, as already illustrated in (21), default agreement inversion requires tonal reduction, and does so even when the subject is not in narrow focus. When the sentence has a thetic interpretation, that is, everything is presented as one piece of (new) information (28), tonal reduction applies. ${ }^{11}$
TR Hiij' ómuuntu.
ha-a-ija o-mu-ntu
16SM-N.PST-come AUG-1-person
'Someone has come.'

There is one indication that tonal reduction does have a focus effect on the following element, which is the case of an adverb and a right-dislocated object, as in (29). As indicated in the translations, the adverb that directly follows the verb does not have a special interpretation when preceded by a non-reduced verb form (29a), but is in focus when the verb is tonally reduced (29b). This can be seen as an optional inclusion of the adverb inside the $\mathrm{vP}$, hence an indirect relation with focus.
a. H Píta
y-áá-ka-téek'
e-ri-zóob' a-ka-húúnga.
1.Peter 1SM-N.PST-12OM-cook AUG-5-day AUG-12-posho
'Peter cooked it today, posho.'
b. TR Píta y-aa-ka-teek' é-ri-zóob' á-ka-húúnga.
1.Peter 1SM-N.PST-12OM-cook AUG-5-day AUG-12-posho
'Peter cooked posho today.'

3.4 Postverbal focus requires TR The last potential correlation between the verb form and focus is true for all languages with the conjoint/disjoint alternation: postverbal focused elements require the tonally reduced ('conjoint') form. Wh words, answers to wh questions, and DPs with an exhaustive focus particle 'only' or an additive particle 'even/also' all require the tonally reduced form, as shown in (30) to (33).
a. TR Jéin y-aa-korá ki?
1.Jane 1SM-N.PST-do what
'What did Jane do?'
b. H *Jéin y-áá-kóra kí?

\footnotetext{
${ }^{11}$ It is interesting to note that liaison between the verb and postverbal object does still apply. We leave this "mismatch" between tonal phrasing and liaison to one side for now.
} 
(31) a. TR Hélen atwiiré ki?

Helen a-twar-ire ki

1.Helen 1SM-take-PFV what

'What did Helen take?'

b. TR Hélen atwiir' ékikópo.

Helen a-twar-ire e-ki-kopo

1.Helen 1SM-take-PFV AUG-7-cup

'Helen took a cup.'

c. H *Hélen atwíire/atwííre ekikópo.

a. TR Píta y-aa-teeká a-ka-húúngá k-ónka.

1.Peter 1SM-N.PST-cook AUG-12-posho 12-only

'Peter cooked only posho.' ${ }^{12}$

b. H *Píta y-áá-téeká a-ka-húúngá k-ónka.

(Have you seen an old car?)

a. TR yeego, n-aa-reebá n' é-n-sya.

yes 1SG.SM-N.PST-see and AUG-9.new

'Yes, and I also saw a new one.'

b. H yeego n' é-mótoka n-syá n-áá-gí-reeba.

yes and AUG-9.car 9-new 1SG.SM-N.PST-9OM-see

'Yes, and the new car I have also seen.'

However, this can alternatively be explained as an indirect relation, similar to Zulu. As in Zulu, focused postverbal phrases in Rukiga prefer to be adjacent to the verb, as exemplified for the wh object in (34): the intervening recipient object is left- or right-dislocated in order for the interrogative theme object to be adjacent to the verb.

a. Káák' á-bá-ana y-aa-ba-há ki?

1.grandmother AUG-2-children 1SM-N.PST-2OM-give what

'What has grandmother given the children?'

b. Kááka y-aa-ba-ha ky á-bá-ana?

1.grandmother 1SM-N.PST-2OM-give what AUG-2-children

'What has grandmother given the children?'

c. *Kááka y-aa-h' á-b-áána ki?

1.grandmother 1SM-N.PST-give AUG-2-children what int. 'What has grandmother given the children?'

This implies that focused elements need to occupy a position internal to the verb phrase, and as a result the verb is not phrase-final, therefore undergoing tonal reduction. This also explains the focus interpretation of the adverb in (29): when 'yesterday' is focused, it occurs inside the vP and therefore the verb undergoes tonal reduction.

${ }^{12}$ Posho is the Ugandan equivalent of ugali, a stiff mass made from corn flour. 
3.5 Finality. The tests in the previous subsections do not provide evidence for a direct relation between verb form and focus; instead, most of the data argue against a focus-based account of the alternating tonal forms in Rukiga. The only relevant factor seems to be whether the verb occurs in a constituent-final position or not. This is also clear in the minimal pair in (35). When preceded by a tonally reduced form, na-we 'and-1.PRO' is part of the same phrase and hence translated as 'with $\mathrm{him} / \mathrm{her}$ ', whereas a preceding non-TR form triggers the interpretation 'and him, he too', referring back to the subject. This is the same as the pattern Creissels (1996) describes for the (equally constituency-sensitive) conjoint/disjoint alternation in Setswana.
a. TR Dániel a-gaamb-ire ná-we.
1.Daniel 1SM-talk-PFV and-1.PRO
'Daniel spoke with him.'
b. H Dániel a-gaamb-íre ná-we.
1.Daniel 1SM-talk-PFV and-1.PRO
'Daniel also spoke.'

The overall picture, then, is that there is never a true minimal choice between applying TR or not, that is, there is no alternation depending on information structure, but rather a tonal rule that is sensitive to (some) constituency boundaries. There is no direct tonal marking of focus (see Hyman 1999). The options available to the speaker are to phrase a postverbal element within or outside of the same constituent as the verb, and the form of the verb follows automatically.

\section{Conjoint/disjoint or just phonology?}

Considering the conclusion that tonal reduction in Rukiga is sensitive to constituency, we can now return to our overall research question: should the opposition between tonal reduction and retaining $\mathrm{H}$ tones on verbs in Rukiga be analysed as encoding the conjoint/disjoint alternation? For Bemba, Kula (2017) discusses a similar question. Bemba has a number of alternating tenses with two segmentally marked forms, and in addition $\mathrm{H}$ tones can spread in a bounded fashion (when not final in the phonological phrase) or unbounded (when final in the phonological phrase). The resulting tonal differences for final vs. non-final verbs are reminiscent of the Haya and Rukiga situation, but there is a crucial difference: the tonal rules in Bemba, that is, bounded vs. unbounded $\mathrm{H}$ tone spreading, apply across the board, leading Kula to conclude that "tone does not encode the CJ/DJ alternation in Bemba" (Kula 2017: 270). In contrast, tonal reduction in Rukiga is only present in four conjugational categories (or 'tenses'). Since it does not apply in infinitives, progressives, subjunctives and the far future tense, as seen in Table 4 and Table 5, and in (36), TR cannot be analysed as a general phonological rule that marks any and all phonological phrases in the language.

$$
\begin{aligned}
& \text { a. Kat' á-ryáá-reeba. } \\
& \text { 1.Kato 1SM-FUT-see } \\
& \text { 'Kato will see.' }
\end{aligned}
$$

b. Kat' á-ryáá-reeb' óó-ha?

1.Kato 1SM-FUT-see 1-who

'Who will Kato see?'

The system is therefore more similar to the tonal marking of the conjoint/disjoint alternation as found in Setswana, which is also restricted in the number of conjugational categories where it applies (Creissels 1996, 2017). On the basis of the current data, we thus conclude that tonal 
reduction in Rukiga indeed encodes the conjoint/disjoint alternation. To our knowledge, this is the first time a purely tonal conjoint/disjoint system has been described.

If it is true that the conjoint/disjoint alternation existed in the ancestor of the Eastern Bantu languages (Nurse 2008, Güldemann 2003, Van der Wal \& Hyman 2017), this suggests that Rukiga has lost the segmental morphology, while so far retaining the tonal distinction as a marker of the conjoint/disjoint alternation. Considering the lack of segmental morphology, and the various other tonal rules that obfuscate the tonal patterns on verbs, it remains to be seen how stable tonal reduction as an alternation will remain for future acquirers of Rukiga. ${ }^{13}$

Further questions concern the tonal patterns in relative verbs, as well as how tonal reduction on verbs in Rukiga compares to the tonal behaviour within its nominal domain, where a closer or looser relation between nouns and modifiers is also observed (see Poletto 1988b for Runyankore; Byarushengo et al. 1976, Hyman \& Byarushengo 1984, and Hyman 1999 for Haya; Hyman \& Katamba 2010 and earlier for Luganda; Kula 2017 for Bemba).

\section{Acknowledgements}

The research reported here is part of the BaSIS project, funded by NWO Vidi grant 276-78-001. We are grateful to Pamellah Geiga Birungi, Joel Tumusiime and Ronald Twesigomwe for sharing their knowledge with us, and to Larry M. Hyman for his speedy and helpful comments on an earlier draft. Any errors remain ours alone.

\section{Abbreviations and symbols}

We write all vowel length (phonemic and automatic) with 2 vowels. Orthographic $|\mathrm{k}|$ and $|\mathrm{g}|$ before [i], as well as $|\mathrm{ky}|$ and $|\mathrm{gy}|$ before other vowels, are pronounced [t $\mathrm{f}$ ] and [dz], respectively. Liaison between words is indicated by an apostrophe. When surface morphology is not transparent, a second line is added in examples, showing the underlying morphemes. High tones are indicated by an acute accent, low tones are unmarked.

$\begin{array}{ll}\text { APPL } & \text { applicative } \\ \text { AUG } & \text { augment } \\ \text { CJ } & \text { conjoint } \\ \text { COP } & \text { copula } \\ \text { DAI } & \text { default agreement inversion } \\ \text { DEM } & \text { demonstrative } \\ \text { DJ } & \text { disjoint } \\ \text { FPST } & \text { far past } \\ \text { FUT } & \text { future tense } \\ \text { FV } & \text { final vowel } \\ \text { H } & \text { high tone } \\ \text { int. } & \text { intended meaning } \\ \text { L } & \text { low tone } \\ \text { LOC } & \text { locative } \\ \text { NEG } & \text { negation } \\ \text { N.PST } & \text { near past } \\ \text { OM } & \text { object marker } \\ \text { P1 } & \text { past } \\ \text { PCF } & \text { predicate-centred focus } \\ & \end{array}$

\footnotetext{
${ }^{13}$ Considering the many conjugations formed by auxiliaries, we can speculate that these might morphologise and be pressed into service to form a new disjoint form.
} 


$\begin{array}{ll}\text { PERS } & \text { persistive } \\ \text { PFV } & \text { perfective aspect } \\ \text { PRS } & \text { present tense } \\ \text { PST } & \text { past tense } \\ \text { QW } & \text { question word } \\ \text { REF } & \text { reference } \\ \text { REM } & \text { remote (past) } \\ \text { SM } & \text { subject marker } \\ \text { TR } & \text { tonal reduction }\end{array}$

\section{References}

Buell, Leston C. 2005. Issues in Zulu morphosyntax. Los Angeles: University of California. PhD dissertation.

Buell, Leston C. 2006. The Zulu conjoint/disjoint verb alternation: focus or constituency? ZAS Papers in Linguistics 43. 9-30.

Buell, Leston C. 2009. Evaluating the immediate postverbal position as a focus position in Zulu. In Masangu Matondo, Fiona Mc Laughlin \& Eric Potsdam 35 (eds.), Selected Proceedings of the 38th Annual Conference on African Linguistics: Linguistic Theory and African Language Documentation, 166-172. Somerville, MA: Cascadilla Proceedings Project.

Cheng, Lisa L. \& Laura J. Downing. 2009. Where's the topic in Zulu? In Helen de Hoop \& Geertje van Bergen (eds.), Special issue on Topics Cross-linguistically, The Linguistic Review 26, 207-238.

Creissels, Denis. 1996. Conjunctive and disjunctive verb forms in Setswana. South African Journal of African Languages 16 (4). 109-115.

Creissels, Denis. 2017. The conjoint/disjoint distinction in the tonal morphology of Tswana. In Van der Wal, J. and 1. M. Hyman (eds.), The conjoint/disjoint alternation in Bantu, 200-238. Berlin: De Gruyter.

Güldemann, Tom. 2003. Present progressive vis-à-vis predication focus in Bantu: A verbal category between semantics and pragmatics. In (eds.), Studies in Language, 323-360. Amsterdam: John Benjamins.

Halpert, Claire. 2017. Prosody/syntax mismatches in the Zulu conjoint/disjoint alternation. In Van der Wal, J. and L. M. Hyman (eds.), The conjoint/disjoint alternation in Bantu, 329-349. Berlin: De Gruyter.

Hyman, Larry M. 1999. The interaction between focus and tone in Bantu. In Georges Rebuschi \& Laurie Tuller (eds.), The Grammar of Focus, Amsterdam: John Benjamins.

Hyman, Larry M. \& Ernest R. Byarushengo. 1984. A Model of Haya Tonology. In G. N. Clements \& J. Goldsmith (eds.), Autosegmental Studies in Bantu Tone 3, 53-103. Dordrecht: Foris Publications.

Hyman, Larry M. and John Watters. 1984. Auxiliary focus. Studies in African Linguistics 15. 233273.

Kula, Nancy C. 2017. The conjoint/disjoint alternation and phonological phrasing in Bemba. In Van der Wal, J. and L. M. Hyman (eds.), The conjoint/disjoint alternation in Bantu, 258-294. Berlin: De Gruyter.

Maho, Jouni F. 2009. NUGL Online: The online version of the new updated Guthrie list, a referential classification of the Bantu languages. Available at: goto.glocalnet.net/mahopapers/nuglonline.pdf.

Marten, Lutz \& Jenneke van der Wal. 2014. A typology of Bantu inversion constructions. Linguistic Variation 14 (2). 318-368.

Morris, Heny F. and Brian E. R. Kirwan. 1972. A Runyankore-Rukiga Grammar. East African Literature Bureau: Nairobi, Kampala, Dar-es-salaam. 
Ngoboka, Jean Paul and Jochen Zeller. 2017. The conjoint/disjoint alternation in Kinyarwanda. In van der Wal, J. and L. M. Hyman (eds.), The conjoint/disjoint alternation in Bantu, 350-389. Berlin: De Gruyter.

Nshemezimana, Ernest and Koen Bostoen. 2017. The conjoint/disjoint alternation in Kirundi (JD62): a case for its abolition. In Van der Wal, J. and L. M. Hyman (eds.), The conjoint/disjoint alternation in Bantu, 390-425. Berlin: De Gruyter.

Nurse, Derek. 2008. Tense and aspect in Bantu. Oxford: Oxford University Press.

Poletto, Robert E. 1998a. Topics in Runyankore Phonology, PhD Dissertation. The Ohio State University.

Poletto, Robert E. 1998b. Syntax and tone in Runyankore. OSU Working Papers in Linguistics 51. 95-146.

Taylor, Charles. 1985. Nkore-Kiga. London: Croom Helm.

Van der Spuy, Andrew. 1993. Dislocated noun phrases in Nguni. Lingua 90. 335-355.

Van der Wal, Jenneke. 2011. Focus excluding alternatives: Conjoint/disjoint marking in Makhuwa. Lingua 121 (11). 1734-1750.

Van der Wal, Jenneke. 2017. What is the conjoint/disjoint alternation? Parameters of variation. In Van der Wal, J. and L. M. Hyman (eds.), The conjoint/disjoint alternation in Bantu, 14-60. Berlin: De Gruyter.

Jenneke van der Wal <vjennekevanderwal@gmail.com>

Leiden University

Leiden, the Netherlands

Allen Asiimwe <asiimwea94@gmail.com>

Makerere University

Kampala, Uganda 